\title{
Ticks on Didelphis albiventris from a Cerrado area in the Midwestern Brazil
}

Author(s): Érica Fernanda G. Gomes De Sá, Vinicius Da Silva Rodrigues, Marcos ValéRio Garcia, Namor Pinheiro Zimmermann, Vanessa Do Nascimento Ramos, Isabella Maiumi Zaidan Blecha, Pâmella De Oliveira Duarte, Thiago Fernandes Martins, Marcelo Oscar Bordignon \& Renato Andreotti

Source: Systematic and Applied Acarology, 23(5):935-945.

Published By: Systematic and Applied Acarology Society

URL: http://www.bioone.org/doi/full/10.11158/saa.23.5.11

BioOne (www.bioone.org) is a nonprofit, online aggregation of core research in the biological, ecological, and environmental sciences. BioOne provides a sustainable online platform for over 170 journals and books published by nonprofit societies, associations, museums, institutions, and presses.

Your use of this PDF, the BioOne Web site, and all posted and associated content indicates your acceptance of BioOne's Terms of Use, available at www.bioone.org/page/terms_of_use.

Usage of BioOne content is strictly limited to personal, educational, and non-commercial use. Commercial inquiries or rights and permissions requests should be directed to the individual publisher as copyright holder. 


\title{
Ticks on Didelphis albiventris from a Cerrado area in the Midwestern Brazil
}

\author{
ÉRICA FERNANDA G. GOMES DE SÁ ${ }^{1}$, VINICIUS DA SILVA RODRIGUES ${ }^{2}$, MARCOS \\ VALÉRIO GARCIA ${ }^{3}$, NAMOR PINHEIRO ZIMMERMANN ${ }^{4}$, VANESSA DO NASCIMENTO \\ RAMOS $^{5}$, ISABELLA MAIUMI ZAIDAN BLECHA ${ }^{6}$, PÂMELLA DE OLIVEIRA DUARTE ${ }^{2}$, \\ THIAGO FERNANDES MARTINS ${ }^{7}$, MARCELO OSCAR BORDIGNON ${ }^{8}$ \& RENATO \\ ANDREOTTI $^{* *}$
}

Érica Fernanda G. Gomes de Sá, e-mail adresses: ericafernanda12@gmail.com

Vinicius da Silva Rodrigues, e-mail adresses: vinicius_srod@hotmail.com

Marcos Valério Garcia, e-mail adresses: marcosvagar@gmail.com

Namor Pinheiro Zimmermann, e-mail adresses: namorvet@gmail.com

Vanessa do Nascimento Ramos, e-mail adresses: vanvanecologia@gmail.com

Isabella Maiumi Zaidan Blecha, e-mail adresses: isablecha@hotmail.com

Pâmella de Oliveira Duarte, e-mail adresses: pamella.duarte@hotmail.com.br

Thiago Fernandes Martins, e-mail adresses: thiagodogo@hotmail.com

Marcelo Oscar Bordignon, e-mail adresses: marcelo.bordignon@ufms.br

Renato Andreotti, e-mail adresses: renato.andreotti@embrapa.br

${ }^{1}$ Programa de Pós-Graduação em Biologia Animal, Centro de Ciências Biológicas e da Saúde, Universidade Federal de Mato Grosso do Sul, Cidade Universitária s/n, Caixa Postal 549, 79070-900, Campo Grande, MS, Brasil.

${ }^{2}$ Pós-Graduação em Doenças Infecciosas e Parasitárias - FAMED - UFMS, Campo Grande, MS, Brasil/ Laboratório de Biologia do Carrapato, Embrapa Gado de Corte, Campo Grande, MS, Brasil.

${ }^{3}$ Laboratório de Biologia do Carrapato, EMBRAPA Gado de Corte, Campo Grande, MS, Brasil/ Bolsista DCR Fundect, MS

- Governo do estado de Mato Grosso do Sul.

${ }^{4}$ Centro Universitário da Grande Dourados, Dourados, MS.

${ }^{5}$ Pós-doutoranda em Ecologia de carrapatos - Faculdade de Medicina Veterinária e Zootecnia da USP, São Paulo, SP. Brasil.

${ }^{6}$ Programa de Pós-graduação Ciência Animal Universidade Federal de Mato Grosso do Sul-Brasil/Embrapa Gado de Corte, Campo Grande, MS, Brasil.

${ }^{7}$ Departamento de Medicina Veterinária Preventiva e Saúde Animal - Faculdade de Medicina Veterinária e Zootecnia - Universidade de São Paulo, São Paulo, SP, Brasil.

${ }^{8}$ Centro de Ciências Biológicas e da Saúde, Universidade Federal de Mato Grosso do Sul, 79070-900 Campo Grande, Mato Grosso do Sul, Brasil.

${ }^{9 *}$ Embrapa Gado de Corte, Campo Grande, MS, Brasil.

*corresponding author: Renato Andreotti, Embrapa Gado de Corte, Campo Grande, MS, Brasil. Campo Grande, MS, Brazil, e-mail adresses: renato.andreotti@embrapa.br

\begin{abstract}
This experiment studied tick fauna associated to Didelphis albiventris Lund 1840 from a Cerrado area (Mato Grosso do Sul State, non-adjoining to Pantanal) inserted in a pasture and agricultural activities matrix, with few natural preserved forest patches. Authors also summarized data on ticks parasitizing Didelphis spp. in Brazil, and discussed infestation patterns in different biomes and locations. Study took place in Cervinho Farm, Bandeirantes Municipality. For captures, Tomahawk-like traps were distributed along two forest patches (30 each) during five nights. Captures occurred monthly (July/2013 to September/2014), sampling both fragments on alternate months. Animals were sedated and ticks were collected and stored in vials containing ethanol (70\%) for identification. $51 \mathrm{D}$. albiventris were captured in 15 campaigns. Tick prevalence was $100 \%$, and $49.5 \%$ of the animals were co-infested by two or more tick species. Four parasitizing species were found: Amblyomma sculptum Berlese, 1888 (78 nymphs), Ixodes loricatus Neumann, 1899 (56 adults), Amblyomma dubitatum Neumann, 1899 (45 nymphs), Amblyomma coelebs Neumann, 1899 (32 nymphs) and Amblyomma sp. (123
\end{abstract}


larvae). A. sculptum was the most abundant tick, but most frequent species were A. coelebs and A. dubitatum, followed by $I$. loricatus. Co-occurrences of more than two species were observed among all tick pairs. $D$. albiventris usually presents high prevalence of tick infestation. However, this study presented $100 \%$ prevalence. Knowledge of host-parasite relation and interactions between different ticks that coexist on a same host are essential, since such interaction may favor pathogen dissemination. This is of special relevance regarding $D$. albiventris, known for participating in maintenance of ecological cycles of Spotted Fever Group rickettsiae.

Keywords: Opossum, Central West, Ticks, Co-infestation, Brazil

\section{Introduction}

The white-eared opossum, Didelphis albiventris Lund 1840, is a widespread didelphid marsupial in the Neotropical region that inhabits savannahs, gallery and humid forests (Emmons \& Feer 1997). This species exhibits omnivorous and opportunistic feeding habits, presenting a great adaptability to disturbed landscapes (Cáceres \& Monteiro-Filho, 2006), including to urban areas.

The synanthropic behavior of $D$. albiventris enables this species to participate, in some level, of the epidemiological cycle of human diseases (Muller et al. 2005). In Brazil, Didelphis spp. is the most important marsupial genus which harbors ectoparasites (Linardi 2006), mainly fleas and ticks. Ticks are among the most significant vectors for human diseases (Hoskins \& Cupp 1988). Many of the tick-borne pathogens are also found in opossums (Melo et al. 2016), this animal can participate in the epidemiological cycle of Rickettsia rickettsii (Horta et al. 2009), the responsible agent for causing the Brazilian Spotted Fever (Parola et al. 2013).

Recently, Sponchiado et al. (2015) revealed, in five municipalities located in the Mato Grosso do Sul State, a great richness of tick species infesting this opossum in various fragments of Cerrado at the border of the Pantanal. The number of species was higher than the commonly observed on this host. It is reasonable to suppose that the ixodid fauna associated with this host in more preserved areas, as described by Sponchiado et al. (2015), could be more diverse than the ones from anthropogenic sites. To this respect, for detecting the existence of interaction patterns, or variations in these patterns, it is needed to characterize the tick fauna of this marsupial from areas under various disturb conditions and located in different biomes. In this sense, we presented data on the tick fauna associated to D. albiventris from a Cerrado area in the Mato Grosso do Sul State (non-adjoining to the Pantanal), inserted in a matrix of pastures and agricultural activities, and with few natural and preserved forest patches. In addition, we summarized the data from the literature on ticks parasitizing Didelphis spp. in Brazil, and provided a discussion regarding infestation patterns in different biomes and localities.

\section{Material and methods}

The field study was carried out in the Cervinho Farm (19 $9^{\circ} 55^{\prime}$ 04” S; 54 21' 50" W, 560m a.s.1.), Bandeirantes Municipality, Mato Grosso do Sul State. This farm is within the Cerrado biome, in the Midwestern Brazil, and encompasses an area that presents a few preserved patches mixed with agricultural and cattle ranching activities. Sixty Tomahawk-like traps $(45 \times 21 \times 21 \mathrm{~cm})$ were distributed along two forest patches (30 in each), during five nights. The traps were baited with two mixtures; banana, pineapple essence and corn flour, and canned sardine with corn flour. The captures occurred monthly from July 2013 to September 2014, and the two forest fragments were sampled on alternate months, resulting in 2,250 night-traps. In each campaign, all working traps were daily checked and the bait was replaced. Initially, the captured animals were mechanically restrained for 
body weight measuring (electronic balance SF-40). Afterward, they were anesthetized with Tiletamin-Zolazepam (Zoletil $®)$ for determination of age, sex, application of numerical ear tags and collection of ticks. The animals were released in its capture area after the fully recover from the anesthesia. Ticks were maintained in ethanol $(70 \%)$ until taxonomic identification according to dichotomous keys and descriptions (Onofrio et al. 2006; Onofrio et al. 2009; Martins et al. 2010a; Martins et al. 2016; Nava et al. 2014) and comparison with specimens from reference collection. The larvae were retained at the genus level. Mean infestation intensity, mean abundance and prevalence, according to Bush et al. (1997), were used to describe ticks infestation on hosts. Literature data were summarized for describing tick species parasitizing Didelphis spp. in Brazil. For this purpose, only studies presenting clear association between host and tick species and taxonomic identification at species level for ticks were considered.

\section{Results}

Field data: In our campaigns, we inspected a total of 51 specimens of $D$. albiventris, which were captured in all the 15 campaigns. The prevalence of ticks was $100 \%$, and $49.5 \%$ of the animals were co-infested by two or more tick species. Four tick species were found parasitizing this host; Amblyomma sculptum ( $\mathrm{n}=78$ nymphs), Ixodes loricatus ( $\mathrm{n}=56$ adults), Amblyomma dubitatum ( $\mathrm{n}$ $=45$ nymphs), Amblyomma coelebs ( $\mathrm{n}=32$ nymphs), and larvae of Amblyomma sp. $(\mathrm{n}=123)$. A. sculptum was the most abundant tick, but the most frequent ticks were A. coelebs and A. dubitatum, followed by I. loricatus (Table 1). The higher co-infestation rate was verified for three hosts, parasitized by the four tick species (Table 2). Co-occurrences were observed for all pairs of tick species; A. sculptum plus A. dubitatum (occurring in 10 hosts), A. sculptum + A. coelebs $(\mathrm{n}=4), A$. sculptum + I. loricatus $(\mathrm{n}=5)$, A. dubitatum + A. coelebs $(\mathrm{n}=8)$, A. dubitatum + I. loricatus $(\mathrm{n}=$ $10)$, and A. coelebs + I. loricatus $(\mathrm{n}=10)$. The most frequent unique interactions were $A$. sculptum + A. dubitatum $(\mathrm{n}=6)$ and A. dubitatum + A. coelebs + I. loricatus $(\mathrm{n}=5)$. Larvae of Amblyomma sp. peaked in June and July 2014, and A. sculptum nymphs in September 2013. The other tick species were collected in low numbers, but in general, they were concentrated in the dry season (Figure 1).

Literature data: Twenty-eight studies on tick infestations on Didelphis spp. in Brazil were selected from literature (Table 3). Most of them present results for D. albiventris, but some works also include Didelphis aurita and Didelphis marsupialis. The six Brazilian biomes just were investigated, but the majority ( $\mathrm{n}=15$ studies) was carried out in Atlantic Forest areas, followed by Cerrado areas $(\mathrm{n}=11)$. Sixteen tick species are reported on Didelphis spp.: Amblyomma aureolatum, Amblyomma auricularium, Amblyomma brasiliense, A. coelebs, A. dubitatum, Amblyomma fuscum, Amblyomma geayi, Amblyomma humerale, Amblyomma ovale, Amblyomma parkeri, Amblyomma parvum, A. sculptum, Amblyomma yucumense, I. loricatus, Ixodes schulzei, and Ornithodoros mimon. The most frequent tick species was I. loricatus, observed in 14 works, followed by $A$. sculptum, found in nine studies. The former is reported in eight studies conducted within Areas of Conservation (AC's) (05 on D.. aurita in Atlantic Forest and 03 on D. albiventris in Cerrado), one on non-informed area (on D. aurita in Cerrado), and in five outside AC's ( 02 on D. albiventris and 01 on D. aurita in Atlantic Forest and 02 on D. albiventris in Cerrado). The later occurred outside AC's; two in Atlantic Forest, on D. aurita and D. albiventris, and five in Cerrado, one on D. aurita and four on D. albiventris and two studies conducted within Areas of Conservation (AC's) (01 on D. aurita in Atlantic Forest and 01 on D. albiventris in Cerrado). 
TABLE 1. Infestation parameters of ticks collected on Didelphis albiventris from forest fragments in Cerrado areas, Mato Grosso do Sul, Brazil, between July 2013 and September 2014.

\begin{tabular}{lccccc}
\hline Tick species & Infested hosts (n) & Ticks $(\mathrm{n})$ & $\mathrm{P}(\%)$ & MI & MA \\
\hline Amblyomma sculptum & 11 & $78 \mathrm{~N}$ & 21.6 & 7.1 & 1.5 \\
Amblyomma coelebs & 20 & $32 \mathrm{~N}$ & 39.2 & 1.6 & 0.6 \\
Amblyomma dubitatum & 20 & $45 \mathrm{~N}$ & 39.2 & 2.3 & 0.9 \\
Amblyomma sp. & 11 & $123 \mathrm{~L}$ & 21.6 & 11.2 & 2.4 \\
Ixodes loricatus & 18 & 56A (28M, 28F) & 35.3 & 3.1 & 1.1 \\
\hline
\end{tabular}

n: total number; P: prevalence; MI: mean intensity; MA: mean abundance; L: larvae; N: nymph; A: adult; M: males; F: females.

TABLE 2. Number of Didelphis albiventris infested by two or more tick species, in Cerrado areas, Mato Grosso do Sul, Brazil, between July 2013 and September 2014.

\begin{tabular}{ccccc}
\hline Number of hosts with co-infestation & Amblyomma sculptum & Amblyomma coelebs & Amblyomma dubitatum & Ixodes loricatus \\
\hline 6 & $\mathrm{x}$ & $\mathrm{x}$ & $\mathrm{x}$ & $\mathrm{x}$ \\
1 & $\mathrm{x}$ & $\mathrm{x}$ & $\mathrm{x}$ \\
1 & $\mathrm{x}$ & $\mathrm{x}$ & $\mathrm{x}$ \\
3 & & $\mathrm{x}$ & $\mathrm{x}$ \\
5 & & $\mathrm{x}$ & $\mathrm{x}$ \\
1 & $\mathrm{x}$ & $\mathrm{x}$ & $\mathrm{x}$ \\
1 & & & $\mathrm{x}$ \\
\hline
\end{tabular}

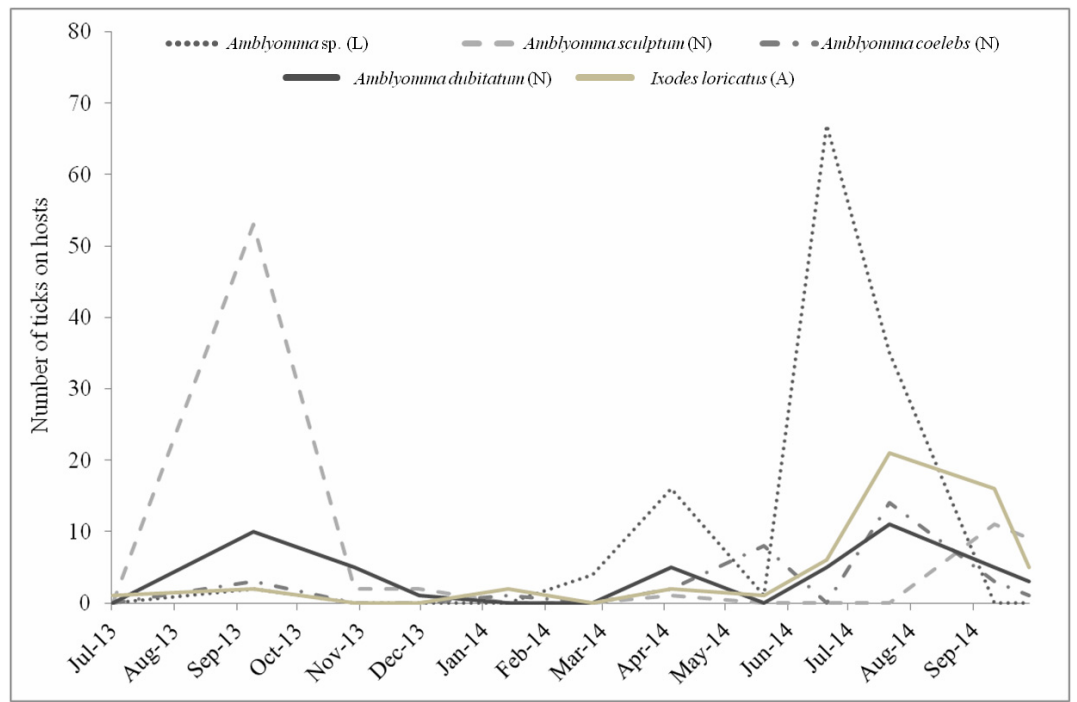

FIGURE 1. Total number of larvae (L), nymphs (N) and adults (A) of ticks collected on Didelphis albiventris in a Cerrado area, Mato Grosso do Sul, Brazil, between July 2013 and September 2014. 
TABLE 3. Reports on the composition of tick species infesting Didelphis spp. in Brazil.

\begin{tabular}{|c|c|c|}
\hline Locality_Biome (Conservation status of the area) & Host species & Ticks \\
\hline 1-Paraná - Atlantic Forest (AC) & D. albiventris, D. marsupialis & Ixodes loricatus \\
\hline 2-São Paulo - Atlantic Forest (AC) & D. aurita & I. loricatus \\
\hline 3-Rio de Janeiro - Atlantic Forest (AC) & D. aurita & Ixodes didelphidis** \\
\hline 4-Rio Grande do Sul - Atlantic Forest, Pampa (OAC) & D. albiventris & Amblyomma aureolatum, I. loricatus \\
\hline 5-Santa Catarina - Atlantic Forest (AC) & D. aurita & A. aureolatum, Amblyomma cajennense*, I. loricatus \\
\hline 6-São Paulo - Atlantic Forest (OAC) & D. albiventris & A. cajennense $*$, Amblyomma dubitatum \\
\hline 7-Mato Grosso do Sul - Cerrado (AC) & D. albiventris & I. loricatus \\
\hline 8-Goiás - Cerrado (AC) & D. albiventris & Amblyomma coelebs \\
\hline 9-Minas Gerais - Atlantic Forest ${ }^{\mathrm{a}, \mathrm{b}}$, Cerrado $^{\mathrm{c}}(\mathrm{OAC})$ & D. aurita & A. cajennense*, I. loricatus, A. coelebs \\
\hline 10-Pernambuco - Atlantic Forest (AC) & D. albiventris, D. aurita & Amblyomma fuscum, I. loricatus \\
\hline 11-Distrito Federal - Cerrado (AC) & D. albiventris & I. loricatus, Ixodes schulzei \\
\hline 12-Rio Grande do Norte - Atlantic Forest (AC) & D. albiventris & Ornithodoros mimon \\
\hline 13-São Paulo - Cerrado (OAC) & D. albiventris & A. cajennense*, A. coelebs \\
\hline $\begin{array}{l}\text { 14-Mato Grosso do Sul - Cerrado bordering the } \\
\text { Pantanal (OAC) }\end{array}$ & D. albiventris & $\begin{array}{l}\text { A. sculptum, A. dubitatum, A. coelebs, Amblyomma } \\
\text { ovale, Amblyomma parkeri, Amblyomma parvum, O. } \\
\text { mimon }\end{array}$ \\
\hline 15-Minas Gerais - Cerrado (OAC) & D. albiventris & A. sculptum, A. dubitatum, I. loricatus \\
\hline 16-Minas Gerais - Cerrado (OAC) & D. albiventris & A. dubitatum, I. loricatus \\
\hline 17-Rio Grande do Sul - Atlantic Forest (OAC) & D. albiventris & A. ovale, I. loricatus \\
\hline 18-Mato Grosso - Pantanal (OAC) & D. albiventris & A. sculptum \\
\hline 19-Mato Grosso - Cerrado ${ }^{\mathrm{a}}$, Amazon Forest ${ }^{\mathrm{b}}(\mathrm{NI})$ & $\begin{array}{l}\text { D. albiventris }{ }^{a b}, D \text {. } \\
\text { marsupialis }^{b}\end{array}$ & $\begin{array}{l}\text { A. coelebs }{ }^{a b}, \text { A. coelebs, Amblyomma humerale, A. } \\
\text { parkeri }^{b}\end{array}$ \\
\hline 20-Espírito Santo - Atlantic Forest (OAC) & D. aurita & A. coelebs, A. dubitatum \\
\hline 21-Santa Catarina - Atlantic Forest (OAC) & D. albiventris & A. ovale \\
\hline 22-Pernambuco - Caatinga (OAC) & D. albiventris & Amblyomma auricularium, A. dubitatum \\
\hline 23—São Paulo - Cerrado (NI) & D. aurita & I. loricatus \\
\hline 24-Pará - Amazon Forest (OAC) & D. marsupialis & Amblyomma geayi, A. humerale \\
\hline 25-Rio Grande do Sul - Atlantic Forest (AC) & D. aurita & Amblyomma yucumense \\
\hline 26-Mato Grosso do Sul - Cerrado (AC) & D. albiventris & A. cajennense* \\
\hline 27-Pernambuco - Atlantic Forest (AC) & D. albiventris & A. fuscum \\
\hline 28—São Paulo - Atlantic Forest (AC) & D. aurita & $\begin{array}{l}\text { A. cajennense } * \text {, Amblyomma brasiliense, A. fuscum, A. } \\
\text { ovale, I. loricatus }\end{array}$ \\
\hline
\end{tabular}

$*$ A. cajennense $=$ A. sculptum; $* *$ I. didelphidis $=$ I. loricatus

$\mathrm{AC}=$ Areas of Conservation, $\mathrm{OAC}=$ outside Areas of Conservation, $\mathrm{NI}=$ non informed

References (coordinates) $=1$ - Barros and Baggio, $1992\left(25^{\circ} 14^{\prime} \mathrm{S}, 50^{\circ} 00^{\prime \prime} \mathrm{W}\right), 2-B o s s i$ et al., $2002\left(24^{\circ} 32^{\prime} \mathrm{S}, 47^{\circ} 15^{\prime} \mathrm{W}\right), 3$-Bittencourt and Rocha, 2003

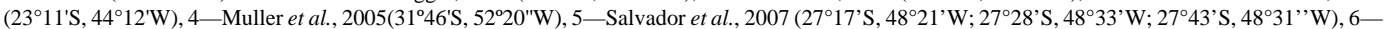

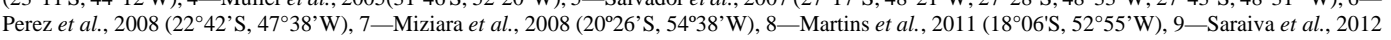

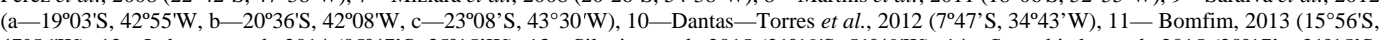
$\left.47^{\circ} 56^{\prime} \mathrm{W}\right), 12$ - Labruna et al., $2014\left(05^{\circ} 47^{\prime} \mathrm{S}, 35^{\circ} 15^{\prime} \mathrm{W}\right), 13$-Silveira et al., $2015\left(21^{\circ} 19^{\prime} \mathrm{S}, 51^{\circ} 49^{\prime} \mathrm{W}\right), 14$-Sponchiado et al., $2015\left(20^{\circ} 17^{\prime}-21^{\circ} 15^{\prime} \mathrm{S}\right.$,

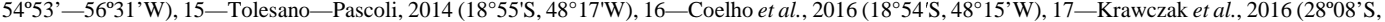

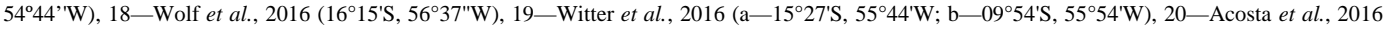
$\left(18^{\circ} 24^{\prime} \mathrm{S}, 40^{\circ} 13^{\prime} \mathrm{W} ; 19^{\circ} 56^{\prime} \mathrm{S}, 40^{\circ} 36^{\prime} \mathrm{W}\right), 21$-Blanco et al., 2017 ( $\left.26^{\circ} 46^{\prime} \mathrm{S}, 48^{\circ} 38^{\prime} \mathrm{W}\right), 22$-Fontalvo et al., $2017\left(09^{\circ} 19^{\prime} \mathrm{S}, 40^{\circ} 33^{\prime} \mathrm{W} ; 08^{\circ} 40^{\prime} \mathrm{S}, 40^{\circ} 08^{\prime} \mathrm{W}\right), 23-$ Martins et al., 2017 (coordinates not informed), 24-Soares et al., 2015 (02 $\left.22^{\circ} 4^{\prime} \mathrm{S} ; 54^{\circ} 42^{\prime} \mathrm{W} ; 04^{\circ} 05^{\prime} \mathrm{S} ; 54^{\circ} 54^{\prime} \mathrm{W}\right), 25$ - Krawczak et al., 2015 (27 $14^{\circ} 26^{\prime \prime} \mathrm{S}$,

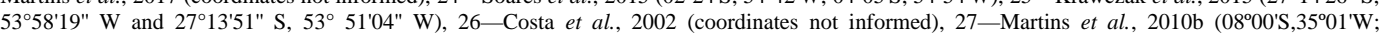
$\left.07^{\circ} 53^{\prime} \mathrm{S}, 35^{\circ} 10^{\prime} \mathrm{W}\right), 28$ - Szabó et al., $2013 \mathrm{~b}\left(24^{\circ} 25^{\prime} 23 \cdot 6^{\prime \prime S} ; 47^{\circ} 03^{\prime} 06 \cdot 6^{\prime \prime} \mathrm{W}\right.$

\section{Discussion}

In our study, I. loricatus and A. sculptum were not the most prevalent on hosts, but they were the most abundant tick species collected on D. albiventris. Amblyomma sculptum is a generalist tick and 
commonly found on this host species, mainly in immature stages (Oliveira, 2004; Estrada-Pena et al. 2004). Ixodes loricatus is also associated to marsupials, but especially the adult ticks (Barros-Battesti et al. 2006).

Both host-parasite interactions between stages and species were reported on our study. Otherwise, the most frequent species were A. coelebs and A. dubitatum. Nymphs of A. coelebs seem to infest a broad host range, and they have been previously reported on $D$. albiventris (Labruna et al. 2002a; Labruna et al. 2005; Martins et al. 2011; Saraiva et al. 2012; Sponchiato et al. 2015). Tapirs (Tapirus terrestris) are the primary hosts for this tick species (Labruna \& Guglielmone 2009), and are commonly reported in this region (Cáceres et al. 2008). Amblyomma dubitatum is a tick that depends on humid areas and parasitizes mainly capybaras, Hydrochoerus hydrochaeris (Aragão, 1936; Nava et al. 2010; Szabó et al. 2007; Queirogas et al. 2012). In this sense, the occurrence of this tick species is essentially associated with the presence of its primary host and adequate environment.

Co-infestation was verified in almost $50 \%$ of the hosts in this study. Co-occurrences of more than two species were common, and it was observed among all tick species pairs. Despite the importance of the interactions of different tick species on individual hosts in mechanisms of pathogens transmission among vectors (Randolph et al. 1996; Szabó et al. 2013a), few studies have mentioned these association patterns.

Didelphis albiventris usually presents high prevalence by ticks. Herein, we described $100 \%$ of prevalence. In the same region of Mato Grosso do Sul, Sponchiado et al. (2015) found 84.38\% of this host species parasitized by ticks. Studies in different regions of the Brazil have reported prevalence ranging from 40 to 100\%, using distinct capture efforts (Coelho et al. 2016; Saraiva et al. 2012; Muller et al. 2005; Dantas-Torres et al. 2012; Sponchiado et al. 2015). In many of these previous reports, $D$. albiventris also exhibits a high intensity of tick infestation. Intensity rates might oscillate due to collection accuracy and duration, behavior and age of hosts, as well as environmental factors, that obviously varies in different studies.

The richness and the composition of species are diversity components that depend on characteristics of each area (biome, preservation condition, phytophysiognomy, matrix) and especially for this parasite, on the presence of primary hosts for each tick species. In disturbed areas of Cerrado, D. albiventris is mainly infested by A. sculptum, A. dubitatum, and I. loricatus (Coelho et al. 2016). Conversely, in areas inserted into most natural matrices, other tick species are described on this host. We observed four tick species infesting $D$. albiventris in a single area, including the three species commonly found in degraded areas as mentioned before. Sponchiado et al. (2015) reported seven tick species in collections performed in a greater number of fragments distributed along five municipalities bordering the Pantanal.

In general, seasonal pattern of ticks is measured by sampling of free-living ticks and collection on hosts during a minimal period of two consecutive years. In this study, occurrences on hosts showed a concentration of larvae and nymphs in drier months, and for the most abundant tick, $A$. sculptum, the nymphs peaked in September of the first year. As explained above, the assessment of the infestation on hosts is variable and depends on many factors. Nevertheless, on-host ticks represent, to some extent, the environmental infestation. Thus, is supposed to expect that, herein, Amblyomma tick species present a seasonal pattern as demonstrated for other areas in Brazil (Labruna et al. 2002b).

Coincident with the broad distribution of $D$. albiventris, which occurs in the six Brazilian continental biomes (Pantanal, Pampa, Caatinga, Amazon, Atlantic Forest and Cerrado) (Roma, 2007), the parasitism by ticks is described in all these regions. Despite the different number of studies conducted in each biome, the reports are concentrated in the last two eco-regions, and the most frequent ticks were, respectively, I. loricatus and A. sculptum. 
Particularly on D. albiventris, I. loricatus was reported in five studies carried out in the Atlantic Forest and in three studies in Cerrado areas, whereas A. sculptum was observed on this host from two areas of Atlantic Forest and from five savannic areas (four from Cerrado). Both ticks occurred inside and outside AC's, in Cerrado and Atlantic Forest. These findings were expected, because these two tick species seem to be associated with microclimatic and vegetation attributes, and not primarily with the biome or conservational status of each area. Amblyomma sculptum is the most collected free-living tick from forest formations in savannic areas (Ramos et al. 2016; Veronez et al. 2010; Souza et al. 2006), and in Atlantic Forest, it is observed in deforested areas, with savannic characteristics. Ixodes spp. are associated to humid forests, and they are frequently found on small mammals from Atlantic Forest and Amazon (Barros-Battesti et al. 2000; Díaz et al. 2009; Arzua et al. 2003; Luz et al. 2013; Martins et al. 2014). In the Cerrado, I. loricatus was reported on hosts from forest phytophysiognomies (Coelho et al. 2016).

It is necessary to mention that some studies from literature are anecdotal notes on infestations, whereas others are systematized works. Therefore, the analyses of infestation parameters have to be careful, as discussed before. Despite this restriction, all of them contribute to the knowledge on richness of tick species on $D$. albiventris. Additionally, the condensed information provides a largescale vision of the association between tick species and this host from diverse vegetal formations in Brazil. Furthermore, it is relevant to connect the comprehension on the host-tick interactions to serological data and future studies on the infection rates by rickettsiae in these ticks.

In this sense, Binder et al. (2017) suggested that $D$. albiventris participate in the maintenance of the ecological cycle of Spotted Fever Group rickettsiae in Mato Grosso do Sul. Thus, similar studies have to be encouraged in areas with great abundance of this marsupial, mainly in patches of urban or peri-urban forests, where $D$. albiventris is especially important because it can be involved with the eco-epidemiological chain of the Brazilian Spotted Fever (Horta et al. 2007; Horta et al. 2009).

\section{Aknowlegdments}

To the Coordenação de Aperfeiçoamento de Pessoal de Nível Superior (Capes), Conselho Nacional de Desenvolvimento Científico e Tecnológico (CNPq), Fundação de Apoio ao Desenvolvimento do Ensino, Ciência e Tecnologia do Estado de Mato Grosso do Sul (Fundect, MS) - Governo do Estado de Mato Grosso do Sul and Embrapa Gado de Corte, Brazil. Fundação de Amparo à Pesquisa do Estado de São Paulo (Fapesp, SP), Brazil. To gentleman Alberto Penze, and Mr. \& Mrs. Afonso and Angelina Cunha, for allowing the research to be conducted on the Cervinho Farm. To Doctor Gustavo Graciolli, for collaborating on the development of field collections.

\section{Conflict of interests}

The authors declare to have no conflict of interest.

\section{References}

Acosta, I.C.L., Martins, T.F., Marcili, A., Soares, H.S., Krawczak, F.S., Vieira, F.T \& Labruna, M.B. (2016) Ticks (Acari: Ixodidae, Argasidae) from humans, domestic and wild animals in the state of Espírito Santo, Brazil, with notes on rickettsial infection. Veterinary Parasitology: Regional Studies and Reports, 3, 66-69. https://doi.org/10.1016/j.vprsr.2016.08.001

Aragão, H. (1936) Ixodidas brasileiros e de alguns paizes limitrophes. Memorias Instituto Oswaldo Cruz. 3, 759- 
843.

https://doi.org/10.1590/S0074-02761936000400004

Arzua, M., Silva, M.A.N., Famadas, K.M., Beati, L. \& Barros-Battesti, D.M. (2003) Amblyomma aureolatum and Ixodes auritulus (Acari: Ixodidae) on birds in southern Brazil, with notes on their ecology. Experimetal \& Applied Acarolology, 31, 283-296. https://doi.org/10.1023/B:APPA.0000010381.24903.1c

Barros-Battesti, D.M., Arzua, M. \& Bechara, G.H. (2006) Carrapatos de importância médico-veterinária da Região Neotropical: Um guia ilustrado para identificação das espécies. Vox/ICTTD-3/Butantan, São Paulo, Brasil, $223 \mathrm{pp}$

Barros, D.M. \& Baggio, D. (1992) Ectoparasites Ixodida Leach, 1817 on wild mammals in the state of Paraná, Brazil. Memorias Instituto Oswaldo Cruz, 87, 291-296. https://doi.org/10.1590/S0074-02761992000200018

Barros-Battesti, D.M., Yoshinari, N.H., Bonoldi, V.L.N. \& Gomes, A.C. (2000) Parasitism by Ixodes didelphidis and I. loricatus (Acari: Ixodidae) on Small Wild Mammals from an Atlantic Forest in the State of São Paulo, Brazil. Journal of Medical Entomology, 37, 820-827. https://doi.org/10.1603/0022-2585-37.6.820

Binder, L.C., Krawczak, F.S., Sponchiado, J., Melo, G.L., Moraes-Filho. J., Nieri Bastos, F.A., Cáceres, N.C. \& Labruna, M.B. (2017) Serosurvey of Rickettsia spp. in small mammals from Mato Grosso do Sul state, Brazil. Ciência Rural, 47, 1-5. http://dx.doi.org/10.1590/0103-8478cr20160476

Bittencourt, E.B. \& Rocha, C.F.R. (2003) Host-ectoparasite Specificity in a Small Mammal Community in an Area of Atlantic Rain Forest (Ilha Grande, State of Rio de Janeiro), Southeastern Brazil. Memorias Instituto Oswaldo Cruz, 98, 793-798. https://doi.org/10.1590/S0074-02762003000600015

Blanco, C.M., Teixeira, B.R., Silva AG., Oliveira, R.C., Strecht, L., Ogrzewalska, M. \& Lemos, E.R.S. (2017) Microorganisms in ticks (Acari: Ixodidae) collected on marsupials and rodents from Santa Catarina, Paraná and Mato Grosso do Sul states, Brazil. Ticks Tick Borne Disease, 8, 90-98. https://doi.org/10.1016/j.ttbdis.2016.10.003

Bossi, D.E.P., Linhares, A.X. \& Bergalho, H.G. (2002) Parasitic arthropods of some wild rodents from JuréiaItatins Ecological Station, State of São Paulo, Brazil. Memorias Instituto Oswaldo Cruz, 97, 959-963. https://doi.org/10.1590/S0074-02762002000700006

Bush, A.C., Lafterty, K.D., Lotz, J.M. \& Shostak, A.W. (1997) Parasitology meets ecology on its own terms: Margolis et al. revisited. Journal of Parasitology, 83, 575-581. https://doi.org/10.2307/3284227

Cáceres, N.C., Carmignotto, A.P., Fischer, E. \& Santos, C.F. (2008) Mammals from Mato Grosso do Sul, Brazil. Check List, Rio Claro, v. 4, 3, 321-335.

Cáceres, N.C. \& Monteiro-Filho, E.L.A. (2006) Uso Do Espaço Por Marsupiais: Fatores Influentes, Comportamento e Heterogeneidade Espacial, 203-215p. In: Cáceres, N.C., Monteiro-Filho, E.L.A. Os marsupiais do Brasil: Biologia, ecologia e evolução. Campo Grande, Ed. UFMS, 1 ed, 366 pp.

Coelho, M.G., Ramos, V.N., Limongi, J.E., Lemos, E.R., Guterres, A., Costa Neto, S.F., Rozental, T., Bonvicino, C.R., D'Andrea, P.S., Moraes-Filho, J., Labruna, M.B. \& Szabó, M.P.J. (2016) Serologic evidence of the exposure of small mammals to spotted-fever Rickettsia and Rickettsia bellii in Minas Gerais, Brazil. The Journal of Infection in Developing Countries, 1, 275-282. http://dx.doi.org/10.3855/jidc.7084.

Costa, I.P., Bonoldi, V.L.N. \& Yoshinari, N.H. (2002) Search for Borrelia sp. in Ticks Collected from Potential Reservoirs in an Urban Forest Reserve in the State of Mato Grosso do Sul, Brazil: a Short Report. Memorias Instituto Oswaldo Cruz, 97, 631-635. https://doi.org/10.1590/S0074-02762002000500006

Dantas-Torres, F., Aléssio, F.M., Siqueira ,D.B., Mauffrey, J.F., Marvulo, M.F.V., Martins, T.F., Moraes-Filho, J., Camargo, M.C.G.O., D’ Auria, S.R.N., Labruna, M.B. \& Silva, J.C.R. (2012) Exposure of small mammals to ticks and rickettsiae in Atlantic Forest patches in the metropolitan area of Recife, North-eastern Brazil. Parasitology, 139, 83-91.

http://dx.doi.org/10.1017/S0031182011001740

Díaz, M.M., Nava, S. \& Guglielmone, A.A. (2009) The parasitism of Ixodes luciae (Acari: Ixodidae) on marsupials and rodents in Peruvian Amazon. Acta Amazonica, 39, 997-1002. http://dx.doi.org/10.1590/S0044- 59672009000400029 
Emmons, L.H. \& Feer, F. (1997) Neotropical rainforest mammals a field guide, 2 nd ed. Chicago, University of Chicago, $307 \mathrm{pp}$.

Estrada-Pena, A., Guglielmone, A.A. \& Mangold, A.J. (2004) The distribution and ecological 'preferences' of the tick Amblyomma cajennense (Acari: Ixodidae), an ectoparasite of humans and other mammals in the Americas. Annals Tropical Medicine and Parasitology, 98, 283-292. http://dx.doi.org/10.1179/000349804225003316

Fontalvo, M.C., Favacho, A.R.M., Araujo, A.D.C., Santos, N.M., Oliveira, G.M.B., Aguiar, D.M., Lemos, E.R.S. \& Horta, M.C. (2017) Bartonella species pathogenic for humans infect pets, free-ranging wild mammals and their ectoparasites in the Caatinga biome, Northeastern Brazil: a serological and molecular study. Brazilian Journal of Infectious Diseases, 703, 290-296. https://doi.org/10.1016/j.bjid.2017.02.002

Horta, M.C., Labruna, M.B., Pinter, A., Linardi, P.M. \& Schumaker, T.T.S. (2007) Rickettsia infection in five areas of the state of São Paulo, Brazil. Memorias Instituto Oswaldo Cruz, 102, 793-801. http://dx.doi.org/10.1590/S0074-02762007000700003

Horta, M.C., Moraes-Filho, J., Casagrande, R.A., Saito, T.B., Rosa, S.C., Ogrzewalska, M., Matushima, E.R. \& Labruna, M.B. (2009) Experimental Infection of opossums Didelphis aurita by Rickettsia rickettsii and evaluation of the transmission of the infection to ticks Amblyomma cajennense. Vector Borne Zoonotic Diseases, 9, 109-118. http://dx.doi.org/10.1089/vbz.2008.0114.PMid:18945194

Hospkins, J.D. \& Cupp, E.W. (1988) Ticks of veterinary importance. Part I. The ixodidae family: identification, behaviour, and associated diseases. Compendium on Continuing Education for the Practicing Veterinarian, 10, 564-580.

Krawczak, F.S., Binder, L.C., Oliveira, C.S., Costa, F.B., Moraes-Filho, J., Martins, T.F. \& Oliveira, S.V. (2016) Ecology of a tick-borne spotted fever in southern Brazil. Experimental \& Applied Acarology, 70, 219-229. https://doi.org/10.1007/s10493-016-0070-1

Krawczak, F.S., Martins, T.F., Oliveira, C.S., Binder, L.C., Costa, F.B., Nunes, P.H. \& Labruna, M.B. (2015) Amblyomma yucumense n. sp. (Acari: Ixodidae), a parasite of wild mammals in Southern Brazil. Journal of Medical Entomology, 52, 28-37. https://doi.org/10.1093/jme/tju007

Labruna, M.B., Camargo, L.M.A., Terrassini, F.A., Ferreira, F., Schumaker, T.T.S. \& Camargo, E.P. (2005) Ticks (Acari: Ixodidae) from the state of Rondônia, western Amazon, Brazil. Systematic and Applied Acarology, $10,17-32$. https://doi.org/10.11158/saa.10.1.4

Labruna, M.B. \& Guglielmone, A.A. (2009) Ticks of New World tapirs. In: Traeholt, C. (Ed.), Tapir Conservation Houston Zoo Inc., USA, pp. 21-28.

Labruna, M.B., Kasai, N., Ferreira, F., Faccini, J.H.L. \& Gennari, S.M. (2002b) Seasonal dynamics of ticks (Acari: Ixodidae) on horses in the state of São Paulo, Brazil. Veterinary Parasitology, 105, 65-77. https://doi.org/10.1007/s10493-014-9877-9

Labruna, M.B., Marcili, A., Ogrzewalska, M., Barros-Battesti, D.M., Dantas-Torres, F., Fernandes, A.A. \& Venzal, J.M. (2014) New records and human parasitism by Ornithodoros mimon (Acari: Argasidae) in Brazil. Journal of Medical Entomology, 51, 283-287. https://doi.org/10.1603/ME13062

Labruna, M.B., Marrelli, M.T., Heinemann, J.M., Fava, A.B., Cortez, A., Soares, R.M., Sakamoto, S.M., Richtzenhain, L.J., Marinotti, O. \& Schumaker, T.T. (2002a) Taxonomic status of Ixodes didelphidis (Acari: Ixodidae). Journal of Medical Entomology, 39, 135-142. https://doi.org/10.1603/0022-2585-39.1.135

Linardi, P.M. (2006) Os ectoparasitos de marsupiais brasileiros. In: Cáceres, N.C., Monteiro-Filho, E.L.A. Os marsupiais do Brasil: biologia, ecologia e evolução. Editora da Universidade Federal do Mato Grosso do Sul, Campo Grande, pp. 37-52.

Luz, H.R. \& Faccini, J.L.H. (2013) Ticks on Brazilian birds: overview. In: Ruiz, L. \& Iglesias, F. (Ed.). Birds: evolution and behavior, breeding strategies, migration and spread of disease. New York, Nova Science, pp. $97-126$.

Martins, T.F., Barbieri, A.R.M., Costa, F.B., Terassini, F.A., Camargo, L.M.A., Peterka, C.R.L., Pacheco, R.C., Dias, R.A., Nunes, P.H., Marcili, A., Scofield, A., Campos, A.K., Horta, M.C., Guilloux, A.G.A., Benatti, H.R., Ramirez, D.G., Barros-Battesti, D.M. \& Labruna, M.B. (2016) Geographical distribution of Amblyomma cajennense (sensu lato) ticks (Parasitiformes: Ixodidae) in Brazil, with description of the nymph of $A$. 
cajennense (sensu stricto). Parasites and Vectors, 9, 1-14.

https://doi.org/10.1186/s13071-016-1460-2

Martins, T.F., Dantas-Torres, F., Nieri-Bastos, F.A., Marcili, A., Siqueira, D.B., Aléssio, F.M., Mauffrey, J.F., Marvulo, M.F.V., Silva, J.C.R. \& Labruna, M.B. (2010b) Host records for the immature stages of the south american tick, Amblyomma fuscum (Acari: Ixodidae). Entomology News, 120, 370-374. https://doi.org/10.3157/021.120.0404

Martins, T.F., Furtado, M.M., Jácomo, A.T.A., Silveira, L., Sollmann, R., Tôrres, N.M. \& Labruna, M.B. (2011) Ticks on free-living wild mammals in Emas National Park, Goiás State, central Brazil. Systematic and Applied Acarology, 16, 201-206. https://doi.org/10.11158/saa.16.3.2

Martins, T.F., Milanelo, L., Krawczak, F.S., Furuya, H.R., Fitorra, L.S., Dores, F.T., Pedro, V.S., Hippolito, A.G. \& Labruna, M.B. (2017) Diversity of ticks in the wildlife screening center of São Paulo city, Brazil. Ciência Rural, 47, 1-6. https://doi.org/10.1590/0103-8478cr20161052

Martins, T.F., Onofrio, V.C., Barros-Battesti, D.M. \& Labruna, M.B. (2010a) Nymphs of the genus Amblyomma (Acari: Ixodidae) of Brazil: descriptions, redescriptions, and identification key. Ticks and Tick Borne Disease, 1, 75-99. https://doi.org/10.1016/j.ttbdis.2010.03.002

Martins, T.F., Venzal, J.M., Terassini, F.A., Costa, F.B., Marcili, A., Camargo, L.M., Barros-Battesti, D.M. \& Labruna, M.B. (2014) New tick records from the state of Rondônia, western Amazon, Brazil. Experimental \& Applied Acarology, 62, 121-128. http://dx.doi.org/10.1007/s10493-013-9724-4

Melo, A.L.T., Aguiar, D.M.de., Spolidorio, M.G., Yoshinari, N.H., Matushima, E.R., Labruna, M.B. \& Horta, M.C. (2016) Serological evidence of exposure to tick-borne agents in opossums (Didelphis spp.) in the state of São Paulo, Brazil. Brazilian Journal of Veterinary Parasitology, 25, 348-352. http://dx.doi.org/10.1590/S1984-29612016028

Miziara, S.R., Paiva, F., Andreottim R., Koller, W.W., Lopes, V.A., Pontes, N.T. \& Bitencourt, K. (2008) Occurrence of Ixodes loricatus Neumann, 1899 (Acari: Ixodidae) parasitizing Didelphis albiventris (Lund, 1841) (Didelphimorphia: Didelphidae) in Campo Grande, MS. Revista Brasileira de Parasitologia Veterinaria, $17,158-160$. https://doi.org/10.1590/S1984-29612008000300008

Muller, G., Brum, J.G.W., Langone, P.Q., Michels, G.H., Sinkoc, A.L., Ruas, J.L. \& Berne, M.E.A. (2005) Didelphis albiventris LUND, 1841, parasitados por Ixodes loricatus NEUMANN, 1899, e Amblyomma aureolatum (PALLAS, 1772) (Acari: Ixodidae) no Rio Grande do Sul. Arquivo do Instituto Biologico de São Paulo, 72, 319-324.

Nava, S., Beati, L., Labruna, M.B., Cáceres, A.G., Mangold, A.J. \& Guglielmone, A.A. (2014) Reassessment of the taxonomic status of Amblyomma cajennense (Fabricius, 1787) with the description of three new species, Amblyomma tonelliae n. sp., Amblyomma interandinum n. sp. and Amblyomma patinoi n. sp., and reinstatement of Amblyomma mixtum Koch, 1844, and Amblyomma sculptum Berlese, 1888 (Ixodida: Ixodidae). Ticks and Tick Borne Disease, 5, 252-276. https://doi.org/10.1016/j.ttbdis.2013.11.004

Nava, S., Venzal, J.M., Labruna, M.B., Mastropaolo, M., González, E.M., Mangold, A.J. \& Guglielmone, A.A. (2010) Hosts, distribution and genetic divergence (16S rDNA) of Amblyomma dubitatum (Acari: Ixodidae). Experimental and Applied Acarology, 51, 335-351. https://doi.org/10.1007/s10493-009-9331-6

Oliveira, F.F. \& Langguth, A. (2004) Pequenos mamíferos (Didelphimorphia e Rodentia) de Paraíba e Pernambuco, Brasil. Revista Nordestina de Zoologia, 18, 19-85.

Onofrio, V.C., Barros-Battesti, D.M., Labruna, M.B. \& Faccini, J.L. (2009) Diagnoses of and illustrated key to the species of Ixodes Latreille, 1795 (Acari: Ixodidae) from Brazil. Systematic Parasitology, 72, 143-157. https://doi.org/10.1007/s11230-008-9169-z

Onofrio, V.C., Venzal, J.M., Pinter, A. \& Szabo, M.P.J. (2006) Família Ixodidae: Características gerais, comentários e chave para gêneros. In: Barros-Battesti, D.M., Arzua, M. \& Bechara, G.H. Carrapatos de importância médico-veterinária da região Neotropical: um guia ilustrado para identificação de espécies. São Paulo: Vox/ICTTD-3/Butantan, 223 pp.

Parola, P., Paddock, C.D., Socolovschi, C., Labruna, M.B., Mediannikov, O., Kernif, T., Abdad, M.Y., Stenos, J., Bitam, I., Fournier, P.E. \& Raoult, D. (2013) Update on tick-borne rickettsioses around the world: a geo- 
graphic approach. Clinical Microbiology Reviews, 26, 657-702.

https://doi.org/10.1128/CMR.00032-13

Perez, C.A., Almeida, A.F., Almeida, A., Carvalho, V.H.B., Balestrin, D.C., Guimarães, M..S, Costa, J.C., Ramos, L.A., Santos, A.D.A., Espíndola, C.P.M. \& Barros-Battesti, D.M. (2008) Carrapatos do gênero Amblyomma (Acari: Ixodidae) e suas relações com os hospedeiros em área endêmica para febre maculosa no estado de São Paulo. Revista Brasileira de Parasitologia Veterinária, 17, 210-217. https://doi.org/10.1590/S1984-29612008000400008

Queirogas, V.L., Del Claro, K., Nascimento, A.R.T.\& Szabo, M.P.J. (2012) Capybaras and ticks in the urban areas of Uberlândia, Minas Gerais, Brazil: ecological aspects for the epidemiology of tick-borne diseases. Experimental and Applied Acarology, 57, 75-82. https://doi.org/10.1007/s10493-012-9533-1

Ramos, V.N., Piovezan, U., Franco ,A.H., Rodrigues, V.S., Nava, S. \& Szabó, M.P.J. (2016) Nellore cattle (Bos indicus) and ticks within the Brazilian Pantanal: ecological relationships. Experimental and Applied Acarology, 68, 227-240. http://dx.doi.org/10.1007/s10493-015-9991-3.

Randolph, S.E., Gern, L. \& Nuttall, P.A. (1996) Co-feeding ticks: epidemiological significance for tick-borne pathogen transmission. Parasitology Today, 12, 472-479.

Roma, J.C. (2007) Mapa de cobertura vegetal dos biomas brasileiros. Ministério do Meio Ambiente, Brasil.

Saraiva, D.G., Fournier, G.F., Martins, T.F., Leal, K.P., Vieira, F.N., Câmara, E.M., Costa, C.G., Onofrio, V.C., Barros-Battesti, D.M., Guglielmone, A.A. \& Labruna, M.B. (2012) Ticks (Acari: Ixodidae) associated with small terrestrial mammals in the state of Minas Gerais, southeastern Brazil. Experimental and Applied Acarology, 58, 159-166.

Silveira, I., Martins, T.F., Olegario, M.M., Peterka, C., Guedes, E., Ferreira, F. \& Labruna, M.B. (2015) Rickettsial infection in animals, humans and ticks in Paulicéia, Brazil. Zoonoses Public Health, 62, 525-533.

Soares, H.S., Barbieri, A.R.M., Martins, T.F., Lima, J.T.R., Marcili, A., Gennari, S.M. \& Labruna, M.B. (2015) Ticks and rickettsial infection in the wildlife of two regions of the Brazilian Amazon. Experimental and Applied Acarology, 65, 125-140.

Souza, S.S.A.L., Souza, C.E., Neto, E.J.R. \& Prado, A.P. (2006) Dinâmica sazonal de carrapatos (Acari: Ixodidae) na mata ciliar de uma região endêmica para febre maculosa na região de Campinas, São Paulo, Brasil. Ciência Rural, 36, 887-891.

Sponchiado, J., Melo, G.L., Martins, T.F., Krawczak, F.S., Labruna, M.B.\& Cáceres, N.C. (2015) Association patterns of ticks (Acari: Ixodida: Ixodidae, Argasidae) of small mammals in Cerrado fragments, western Brazil. Experimental and Applied Acarology, 65, 389-401.

Szabó, M.P.J., Castro, M.B., Ramos, H.G.C., Garcia, M.V., Castagnolli, K.C., Pinter, A., Veronez, V.A., Magalhães, G.M., Duarte, J.M.B. \& Labruna, M.B. (2007) Species diversity and seasonality of free-living ticks (Acari: Ixodidae) in the natural habitat of wild Marsh deer (Blastocerus dichotomus) in Southeastern Brazil. Veterinary Parasitology, 143, 147-154.

Szabó, M.P.J., Nieri-Bastos, F.A., Spolidorio, M.G., Martins, T.F., Barbieri, A.M. \& Labruna, M.B. (2013b) In vitro isolation from Amblyomma ovale (Acari: Ixodidae) and ecological aspects of the Atlantic rainforest Rickettsia, the causative agent of a novel spotted fever rickettsiosis in Brazil. Parasitology, 140, 719-728. http://dx.doi.org/10.1017/S0031182012002065

Szabó, M.P.J., Pinter, A. \& Labruna, M.B. (2013a) Ecology, biology and distribution of spotted-fever tick vectors in Brazil. Frontiers in Cellular and Infection Microbiology, 3, 1-9.

Veronez, V.A., Freitas, B.Z., Olegário, M.M.M., Carvalho, W.M., Tolesano-Pascoli, G.V., Thorga, K., Garcia, M.V. \& Szabó, M.P.J. (2010) Ticks (Acari: Ixodidae) within various phytophysiognomies of a cerrado reserve in Uberlândia, Minas Gerais, Brazil. Experimental and Applied Acarology, 50, 169-179.

Witter, R., Martins, T.F., Campos, A.K., Melo, A.L.T., Corrêa, S.H.R., Morgado, T.O., Wolf, R.W., May-Júnior, J.A., Sincok, A.L., Strüssmann, C., Aguiar, D.M., Rossi, R.V., Semedo, T.B.F., Campos, Z., Desbiez, A.L.J., Labruna, M.B. \& Pacheco, R.C. (2016) Rickettsial infection in ticks (Acari: Ixodidae) of wild animals in midwestern Brazil. Ticks and Tick Borne Disease, 7, 415-423. http://dx.doi.org/10.1016/j.ttbdis.2015.12.019

Wolf, R.W., Aragona, M., Muñoz-Leal, S., Pinto, L.B., Melo, A.L.T., Braga, I.A. \& Labruna, M.B. (2016) Novel Babesia and Hepatozoon agents infecting non-volant small mammals in the Brazilian Pantanal, with the first record of the tick Ornithodoros guaporensis in Brazil. Ticks and Tick Borne Disease, 7, 449-456.

Submitted: 2 Feb 2018; accepted by Lidia Chitimia-Dobler: 24 Apr. 2018; published: 23 May 2018 